\title{
An Alternative Shelter Design for Homeless People: A Proposal for Ankara*
}

Evsizlere Yönelik Alternatif Bir Barınma Evi Tasarımı: Ankara İçin Bir Öneri*

Esra ORHAN YILMAZ

Hacettepe University Faculty of Fine Arts, Department of Interior Architecture and Environmental Design, Ankara, Turkey Hacettepe Üniversitesi İç Mimarlık ve Çevre Tasarımı Bölümü, Ankara, Türkiye

orhanesraa@gmail.com

ORCID ID: 0000-0001-7213-2318

\section{Gülçin Cankız ELİBOL}

Assoc. Prof. Dr., Hacettepe University Faculty of Fine Arts, Department of Interior Architecture and Environmental Design, Ankara, Turkey Doç. Dr., Hacettepe Üniversitesi İç Mimarlık ve Çevre Tasarımı Bölümü, Ankara, Türkiye

gcelibol@yahoo.com

ORCID ID: 0000-0002-6529-2855

DOI: $10.5505 /$ jas.2020.22932

\begin{abstract}
Although rapidly developing technologies, increasing living standards and innovations eased our daily lives, various factors such as increasing population, migration movements, hardened life conditions and financial incapability, increased the number of homeless people and scaled up diversification. Nondiscretionary homelessness as a phenomenonis examined within the field of sociology in general, and can simply be defined as a deprivation of "house." Therefore, it is thought that topics regarding the deprivation of "house" can be accepted to have a strong relation with interior architecture and architecture disciplines. Among the initiatives for homelessness, the implementations that propose spatial solutions for homeless people were also selected.

The research was conducted in Ankara (Turkey). With this respect, the governmental implementations providing spatial recommendations for the homeless, who have benn trying to maintain their lives in Ankara province, have been examined in this study. In this stage, "Ankara Metropolitan Municipality Compassion House," providing service for the homeless people, was appeared as the only public establishment in Ankara. Thus, in-depth face-to-face interviews were conducted with the Compassion House officer and three homeless people. These interviews were subjected to content analyses and the results were used in the design process of living space for these individuals. An alternative "house" design was put forward both by these findings and by analysing the existing the Compassion House, in terms of inner and outer spaces of the current construction. The aim was to put
\end{abstract}

* This article is based on a part of the Postgraduate Thesis dissertation entitled “Ankara İli İçin Alternatif Bir 'Barınma Evi' Önerisi," written under the supervision of Assoc. Prof. Dr. Gülçin Cankız Elibol of the Hacettepe University Faculty of Fine Arts, Department of Interior Architecture and Environmental Design.

** Bu makale, Hacettepe Üniversitesi Güzel Sanatlar Enstitüsü İç Mimarlık Anabilim Dalı’nda Doç. Dr. Gülçin Cankız Elibol danışmanliğında gerçekleştirilen "Ankara İli İçin Alternatif Bir 'Barınma Evi' Önerisi” başlıkl yüksek lisans tez çalışmasına dayandırılarak hazırlanmıştır. 
forward a permanent place for homeless people, whose numbers have been increasing. The design was not only expected to provide an alternative to the existing Compassion House in Ankara but was also to be adapted to various users and geographies. A flexible space design was put forward to meet the user's diversified needs by occupying minimum space.

Keywords: Compassion houses, Homeless people, Shelter, Compassion house design, Ankara

\section{$\ddot{O} z$}

Hizl gelişen teknolojiler, artan yaşam standartları ve yenilikler, her ne kadar yaşantımıza kolaylıklar sağlasa da bunlara bağh olarak artan nüfus, göç hareketleri, zorlaşan yaşam koşulları, maddi yetersizlikler gibi çeşitli etkenler, evsiz bireylerin ortaya çıkmasına ve çeşitlenmesine sebep olmuştur. Sosyal bir sorun olarak karşımıza çıkan ve ağırlıklı olarak sosyoloji dalında kendisine yer bulan evsizlik olgusu, "ev"den yoksun olma durumu olarak tanımlanabilir. Dolayısıyla, kişinin hayatın idame edebileceği yerden yoksun olmasının iç mimari ve mimari ile de ilişkili olduğu düşünülmektedir.

Bu doğrultuda çalışmada, Ankara ilinde hayatını idameettirmeye çalı̧̧an bireyler için, devlet tarafından evsizlere yönelikgerçekleştirilen girişimler arasindan mekânsal çözüm önerileri sunan uygulamalar incelenmiştir. İlk incelemelerde evsizlere hizmet veren Ankara Büyükşehir Belediyesi Barınma Evi, konu ile ilgili tek kamu kurumu olması bakımından dikkat çekmiştir. Çalı̧ma kapsamında gerçekleştirilecek tasarım; mevcut Barınma Evi analiz edilerek, burada kalan üç evsiz ve yetkililer ile görüşme gerçekleştirilerek ve mevcut yapının iç-dış mekânlar gözlemlenerek geliştirilmiştir. Çalı̧̧ma kapsamında, günümüzde giderek artmakta olan ve önemli bir sosyal sorun olarak karşımıza çıkan evsiz bireylere çözüm olabileceği düşünülen kahıı bir mekân önerisi sunmak amaçlanmıştır. Mevcut Barınma Evi'ne alternatif olușturması beklenen tasarımın her ne kadar Ankara ilinde bulunan evsizler için kurgulansa da farklı kullanıcılara ve coğrafyalara göre adapte edilebilir olmasına özen gösterilmiştir. Dolayısıyla, evsizlere ya da yoksullara yönelik bir nesne tasarlamaktan ziyade kullanıcı ve mekân ilişkisi beraber irdelenmiştir. Kullanıcı çeşitliliğine cevap verebilecek, kullanıcının ihtiyaçları doğrultusunda geliştirilebilecek, küçük bir alanda ihtiyaçların en yüksek düzeyde karşılanabileceği esnek bir mekân tasarımı kurgulanmıştır.

Anahtar sözcükler: Barınma evleri, Evsizler, Barınak, Barınma evi tasarımı, Ankara

\section{Introduction}

Housing is a basic need for an individual, even in wealth or in poverty. This study mainly approaches to the second condition, as the notion of being homeless is somehow correlated with poverty in general. The need of housing in this meaning, may found correlated with population growth and migration from villages to towns (Densityarchitecture, 2012). Throughouthistory, people found some spatial practical solutions to solve the harbouring problem in the context of "home."

Slums, for instance, are a physical and spatial manifestation of urban poverty and intra-city inequality. However, slums do not accommodate all of the urban poor, nor are all slum dwellers always poor. In general, the locus of poverty is moving to cities, a process now recognized as the "urbanization of poverty." Slum areas have the most visible concentrations of poor people and the worst shelter and environmental conditions, but even the most exclusive and expensive areas will have some low-income people (Un-Habitat, 2003a, xxvi). According to Gilbert, there are no concrete parameters to call a place "slum", as the conditions differ from country to country. Similar to the determination above, he mentions that slum areas are in a heterogeneous structure, hence the poverty based definition has to be assumed as either a certain or a changeable definition (Gilbert, 2007).

Definition of squatter/shanty also shows alteration between resources (Keleş, 2004). In accordance with the detailed definition given in the Kentbilim Terimleri Sözlüğ̈̈ (Glossary for Urbanscience Terms), it can simply be defined as a shelter type which is built over a third party's estate/land without permission, in which usually poor or low-income people live (Keleş, 1998). According to Nazoktabar and Tohidi, shanty town is a phenomenon that economic factors, social and cultural security and lower rates are involved (Nazoktabar and Tohidi, 2014). Sometimes community-led upgrading programs can be conducted regarding these regions. The environmental improvements within this manner include permanent, formal houses with electric, water and sanitation infrastructure provision. Roads can also be built allowing better access to the community (Toomey, 2010). 
Yener (2012), defines compassion houses as non-profit places that provide temporary accommodation to individuals in need. There are just a few number of compassion houses in our country ${ }^{1}$. These compassion houses are subsidiaries of the municipalities. The facilities offered to homeless people in these compassion houses are some basic needs, such as cleaning clothes, bathing and shaving, having a clean and safe bed to sleep, television and recreation rooms for socialising, and breakfast and dinner. In Turkey, compassion houses do not offer an accommodation service that can be used until an individual finds a safe and permanent place to live. A homeless person can only stay in a compassion house for up to 15 days. Each registered homeless individual has a certain time of entry for the house. If someone breaks the time rule, he/she cannot benefit from the compassion house. According to the rules set by the municipalities, it is not enough to be "homeless" to facilitate from these houses. At the same time, this homeless person should be at least 18 years old, should not be alcohol or drug addict and most importantly should be male. If you are a homeless female or a child in the street, your application for the compassion house will not be accepted. It can be seen that the compassion houses in Turkey serve just for males. Whereas in the United Kingdom, single males are not included to the homeless groups; the priority is given to women, children and elderly.

Before examining the models that provide service for the homeless people, examining various attempts made for them will enrich the study. The proposals that previously seek temporary solutions and former projects which were expected to bring permanent solutions around the world will be briefly mentioned.

Figure $1 \mathrm{~A}$ and $1 \mathrm{~B}$ shows a shelter sample which is called as paraSITE and designed for the homeless. This shelter type was designed as inflatable shelters. By attaching the special parts of the shelter to the external vent, the shelter can be inflatable with warm air that comes out from buildings' HVAC system (heating, ventilation, and air conditioning). In this example, which we can call a kind of a tent shaped shelter, the inside temperature was supplied by the air coming out from the vent of the host building. Michael Rakowitz designed paraSITE by using the waste bin bags, with a very low budget (Rakowitz, 1998). The designer created the first sample of his design by using black bin bags. However, homeless people criticized his design and stated that they did not want to use
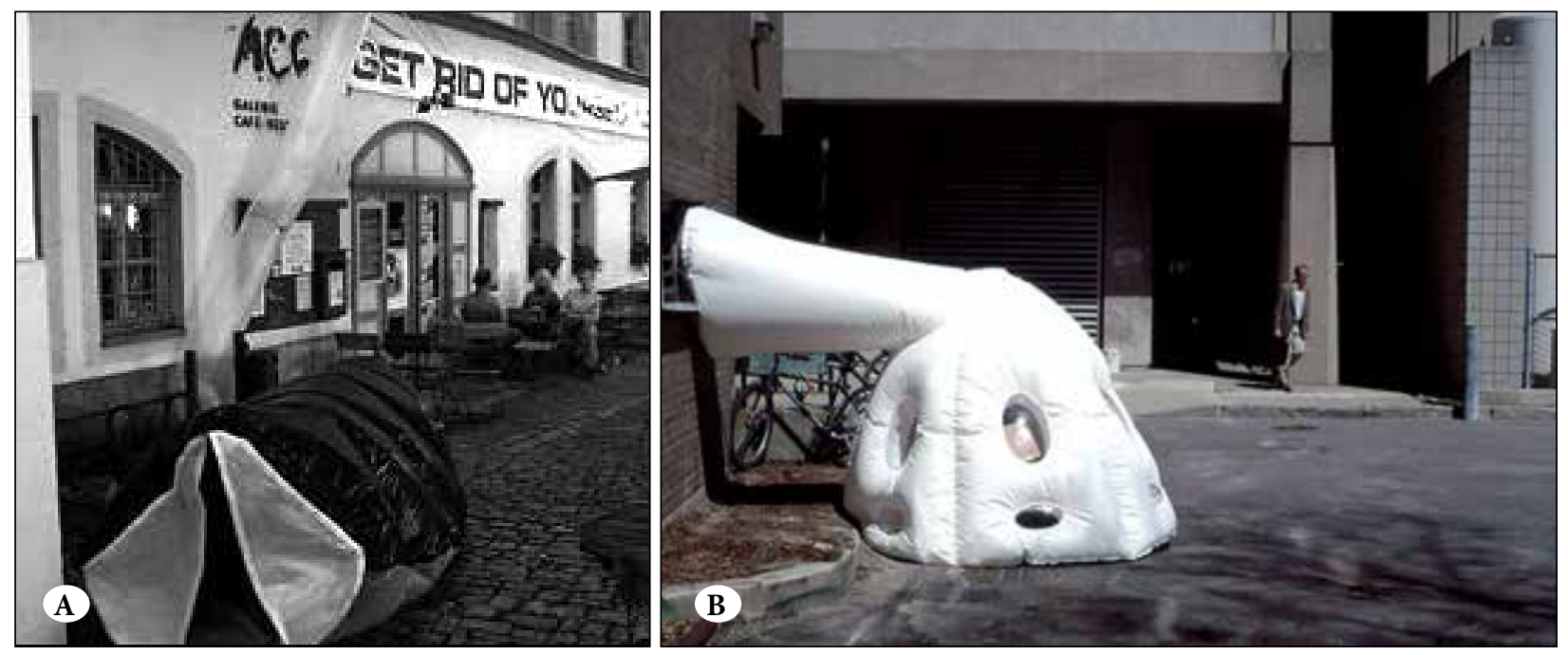

Figure $1 A$ and $1 B$. Different diversification examples about paraSITE model.

Source: Arkitera, 2005; Rakowitz, 1998.

1 There are limited numbers of shanty houses in Turkey, especially in the metropolitans. It can be sampled as Bursa Metropolitan Compassion House, Ankara Metropolitan Municipality Compassion House and İstanbul Governorship Beyoğlu District Governorship Compassion House (Küçük, 2014). 
this shelter. He explained the reason for not preferring to live in a "thing" as he could not see his surrounding and other people when he stays in it. As the homeless person stated further, he could not be seen by other people and he also could not see them in that non-transparent "thing"in which he could not feel safe. At this point, it would not be wrong to say that the importance of some concepts has changed for the homeless. Based on this information, it can be concluded that visual communication is more important than the concept of privacy for homeless people. This approach of the homeless person shows that the void parts of the walls that are in contact with the outside world do not just let the light in, at the same time, it plays an important role in shaping the emotions of the individual living inside and makes the person feel safe. Therefore, the person can control what is happening outside and be alert for the possible threats (Arkitera, 2005). The homeless person, who expressed his discomfort, asked Rakowitz to design a paraSITE with as many windows as possible. The designer redesigned the shelter in accordance with the homeless person's wishesin order to make the homeless person feel safe by using six windows in this shelter type (Rakowitz, 1998).

Another designer who creates some projects for the homeless is James Furzer who is an architect (Figure 2A and 2B). Furzer has been deemed worthy of an award in the design contestentitled 6th Space for New Visions with his project he designed. In his design, Furzer offers homeless people a shelter that they can harbour in rainy and cold weathers or at any time they need. However, the design does not offer a permanent proposal for the homeless. Furzer does not make any classification for homelessness, and defines it as a situation that everyone can facilitate. Two different harbouring projects designed for the homeless were mentioned above. These examples were developed as harbouring offers that can be used in cold days especially, rather than offering a permanent solution for the homeless. Even if any homeless person uses these projects, he/she lacks the basic requirements such as security life and privacy. Therefore, it can be said that these projects do not constitute a permanent solution for the homeless. However, in this study, proposing a permanent home for homeless people is the main aim. Besides, constituting a safe and new life style for homeless people by this means is the subgoal of the study.

It has been observed that there are permanent and solution oriented projects for homeless in Odensa, Denmark and Sydney, Australia. In Odensa city, a project was put into practice for the homeless and the number of homeless people in the city decreased by $47 \%$. One of the most important issues in the project was to provide a cheap home that homeless people can use in the long term. A house was provided to harbour the homeless person, but it also provided help for the people who have drug addiction. The Danish authorities shared their special projects with other cities in Europe (Euronews, 2017); so, it may serve as a model for countries experiencing such matters.

They offered health care and psychological support to the homeless. If we consider it as a whole, the project does not only offer a house for the homeless, it also provides
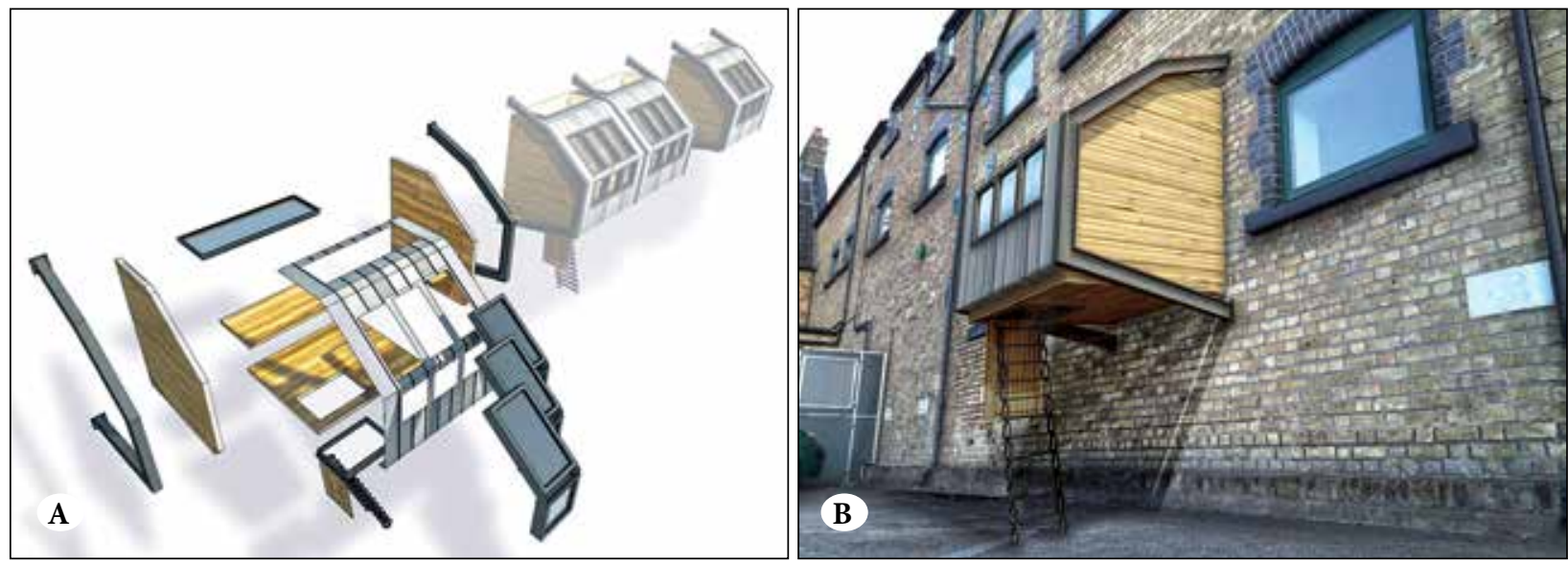

Figure 2. Shelter model designed for the homeless people in London by James Furzer.

Source: Mairs, 2015. 
the necessary services and support for the socialisation of the individual and for him/her to become a healthy individual. Therefore, it was seen that the project offers a holistic approach to the problem of homelessness.

Although there has been no precise number, it was supposed that the number of homeless people in Turkey is over 70 thousand (Batık, 2020, 7 January). This study, takes into consideration the aspect of having a home, and tries to put forward an alternative shelter design, which is designed in regard to the physical, social and psychological needs of homeless people. As this study was conducted within the field of interior architecture, these needs were gathered via face-to-face interviews and the data obtained were taken as design inputs.

In this study, some spatial solution-oriented attempts for the homeless were researched. As can be seen from the examples, we observe that there are limited numbers of attempts that offer permanent solutions. Thus, the framework of the study was limited to the practices carried out by the government in Ankara/Turkey.

The Daily Harbouring House (Barınma Evi), was examined in detail within the scope of the study which was opened to serve people over the age of 18 who lost their home or were expelled from their houses for any reason. Its aim is to protect these people from possible risks that may pose a danger in terms of emotional, social or physical aspects. In addition to this, it is aimed to meet the basic requirements. The Daily Harbouring House started to serve in Ankara in 2009, which has been the source of hope for many homeless people. The Daily Harbouring House plays an important role as it is the only daily harbouring house in Ankara.

When the implementations for homeless people were examined, it was observed that there are quite different attempts. Among these previously mentioned studies conducted for homeless people, it is noteworthy that there are some solution-oriented permanent projects. However, there still is a need for permanent solutions. Considering that the problem of a homeless is not only a lacking house, but also a lacking social life; the study mainly aims to offer a "place" for homeless people in which they can live safely, socialize, become self-sufficient at least by cultivating in his/her way, so on and so forth. As this aim constitutes the backbone of the study, the design inputs were gathered from the opinions of real people, suffering from homelessness.

\section{Method of the Field Study}

Within the scope of the main aim mentioned above, the study had two main parts. The first part consisted of the research made regarding the current implementations. The second part can be defined as the original work, where the data needed is gathered. Within this context, apart from the aids of various associations and volunteers, the attempts made for the homeless people through state channel were examined in Ankara, as it was defined as the research area. It was observed that there are some implementations that offer limited and seasonal services. These implementations are mostly located in Ulus, Ankara. As a result of the primary research made throughout the study, Ankara Metropolitan Municipality has been identified as the only public institution that provides services for the homeless.

Within the limits of the study, the Compassion House, which serves under the Ankara Metropolitan Municipality, has been selected as the sample of the case study. Within the scope of the research, interviews were conducted with one of the officials of the Compassion House and three homeless who were receiving service from the mentioned institution. Face to face interviews were performed and the conversations were recorded. The questions were prepared before the interview. Recorded interviews were transcribed and analysed by using content analysis method. They were then translated into English for the purposes of this study. The researcher paid attention to the protection of privacy. In this respect, the names of the participants were hidden. The photographs of facades and indoors of the construction were taken by permission of the institution. These visuals were taken into consideration throughout the study, in order to the see the current state and to build opinions regarding the places that the homeless people live. As per the limited permissions, these photographs were not placed in the study. Ethical approval was obtained for the study protocol by the decision of Hacettepe University Ethics Commission dated 25/04/2017 and numbered 35853172/431-1757.

The obtained information had an importance on constituting the base of the alternative compassion house suggestion that will be designed. In this respect, defining the problems stated by the official and the users, and supplying a permanent solution, constituted the core of the study. This alternative design was projected 
to provide a permanent solution to the needy homeless individuals rather than offering a seasonal service. The individuals are expected to integrate with the society by this means, and to get better positions in their survivals, as these houses were designed as independent but integratable units of a collective settlement.

\section{Findings of the Field Study}

Apart from being a "place," a Compassion House is also a service model in which people can meet their basic needs. As stated by the Compassion House official, there is an attempt to establish a systematic that adopts the idea of "trying to provide a comfort feeling like home" for the homeless people staying there. Each of the homeless people can take a shower and getcleaning needs, and get clean clothes to wear. Each room is cleaned every day and the sheets are changed every day. Every fifteen days, a hairdresser comes to the Compassion House for the personal cares of the occupants. Besides providing clothes to every person in need, new clothes are provided once a year for every occupant. The breakfasts and dinners are provided free of charge, but no lunch is given.

The standard bed capacity of the Compassion House is limited for 43 people. However, the demand was stated to be in tendency to increase with the low temperatures especially in winter months. Additional beds are placed in the corridors in order to host as many people as possible. Capacity can be increased up to 70 people with additional beds.

The Compassion House was reconditioned in 2014. The official states;

When I came here, there was no parquet. Our doors, toilets and baths were old. There were no tiles on the ground of kitchen; it was in a bad condition. The indoors had a bad smell. The construction was reconditioned extensively on October, 2014. It was closed until January. We could not accept anyone in that period. The constitution was changed from a to $z$. Our restrooms, baths, laundries, dining hall and even our beds have changed. We brought durable and nice beds. The beds are now number one. We did this.

Although the focal point of this study is the homeless people who do not have a place to harbour, it is determined that the masses which are known as "homeless" are deprived of lots of things together with the harbouring problem. "Things" that homeless are deprived of is also supported by scientific bases (Maslow's Hierarchy
Theory)(Un-habitat2003b). If we summarise the basic needs and deprivations of homeless, as stated by the participants, lack of place to harbour, quality nourishment, insufficient access to the clean water, cleaning, regular sleep, health, unhealthy living conditions, security, finding a job, making friends, family, privacy, selfconfidence, self-respect, getting respect from the others, solving problems, social life and positive thinking.

The first interview in this study was conducted with participant number one, a 58-year-old male secondary school graduate who previously worked as a long-haul truck driver using his own vehicle. His financial situation deteriorated over time, he had bankrupted, became estranged from his family and found himself living on the streets. His family and friends know that he lives at the shelter but have not been in touch or provided any help whatsoever since 1998 . He said that his only income is from his son's insurance. He has never received any state benefit and only recently became aware of the shelter. He is happy with the way it is run but since he is $82 \%$ disabled and uses crutches he finds movement between floors in the shelter as a huge problem. Apart from that, as he said: "Eating, drinking and sleeping is enough for us." When he was living on the streets, he took shelter in the emergency rooms of the hospitals. As for eating, he said "If a philanthropist provides us with meals, then we can eat."

The second participant is a 27-year-old male. He had been living under the Sihhiye Bridge (a major highway bridge in the center of Ankara) but found himself in the shelter after a citizen brought him to the attention of municipal authorities. He has not been in touch with his family. He said that when the shelter was not available, he found a place to sleep in a park, preferably one with security staff. The participant is $40 \%$ disabled. He also stressed the difficulty of moving between floors at the shelter for elderly people or those with disabilities. He also said that to avoid loneliness, he prefers a crowded room with other homeless people rather than a single room at the shelter. However, to get a job he sometimes has to study for the exams and would appreciate a space at the shelter for such activities.

Like the participant number three, the last interviewee, is a 58 year-old-male primary school graduate. Retired after working as a government employee, he said that he is receiving a minimal retirement pension and spending 
two-thirds of it paying off his debts. Consequently, the amount left is insufficient for him to lead a normal life. He rarely talks to his son and receives no help from his family. He said that when the shelter is unavailable he walks the streets if the weather is nice. Like the participant number one, he spends time in the emergency rooms of hospitals when he cannot stay at the shelter. Because hospitals are crowded, safe and warm.

After face-to-face interviews with three volunteer homeless participants, an attempt was made to analyze their attitudes towards the shelter and how they survive. In the interviews, all three participants emphasized that safety was as an important problem. When they could not stay at the shelter they looked for a safe place in the streets, gravitating towards the emergency rooms of hospitals or parks with security staff. In addition, participants indicated that movement between floors in the shelter was a problem especially for elderly or disabled people.

As is evident from these statements, although each homeless person has different expectations and needs they agree on a number of topics. Satisfying the need for food, shelter and safety are common among such topics. The participants were asked: "If the government provided you with a house with a very low rental price, would you want to live in it?" and all three answered positively. Participant number three said: "Even if one has only one room, it is enough."

Interviews did not include spatial analyses as the conversations were mostly about the basics of life. Insecurity and loneliness caused by homelessness took priority over spatial preferences. Even having one room was deemed to be sufficient. As a result, in the design of the module, all extras have been removed with the aim of planning the optimal space for day-to-day life at the minimum cost.

\section{An Alternative Shelter: A Living Module}

The purpose of the study was to design a space where an individual can be peaceful, happy and safe rather than offering just a place to shelter. In the research, the individual is seen as a person who needs to be integrated into society. The design aims to create a space that allows the homeless to have the things they have been deprived of, rather than being simply a shell. The structure is designed as a space where a person can be himself. In this context, the structure is designed in such a way that it can be adapted to individuals. In accordance with the informa- tion from the interviews, the aim was to create a userfriendly, flexible, modular and holistic design.

Based on the criteria from the interviews, it is important that the design of the compassion house to be flexible. In addition, for meeting the needs of the users withinthe minimum possible space was the major driver of the design which was the integration of the user and the space. Although the compassion house user is usually defined as homeless, but it should be noted that every homeless person is an individual. The starting point of the study was therefore specified as the user him/herself, as a human. In this context, we calculated the minimum space in which a person can stand and complete basic movements. A person can move more comfortably in an area of $120 \mathrm{~cm}$ but basic movements such as sitting, standing and bending can be carried out by healthy individuals in an area of $100 \mathrm{~cm}$. Also, this dimension was not taken into consideration as a total unit; it was specified as an estimation unit for the whole space. Besides, the dimensions of the doors were assumed to be flexible in order to be compatible to wheelchair users.

The design was created by combining spaces of 100 by 100 centimetres, which was determined as the minimum volume at which a person can meet his needs (Figure 3). The optimum area was determined by creating a grid system. The necessary unit was determined to include the dining area (kitchen), sleeping area, wet space (bathroom-toilet) and living area. When creating the alternative compassion house design, it was decided to create a core module by combining the basic needs of the individual: wet area, kitchen, living space, circulation and storage area.

These spaces had to be as small as possible, which led to a tendency for flexible equipment designs. For example, rather than defining a space exclusively for sleeping in the core module, it was designed to alter the function of the space using equipment that provides flexibility in the living area. As Louis Sullivan says, form follows function (İnan, 2011). In other words, flexibility of design to exploit maximum use of the space was one of the fundamentals of the study.

The design proposal created from 100 by $100 \mathrm{~cm}$ grid systems (Figure 3) was designed as a rectangular mass with sides of 300 and $400 \mathrm{~cm}$. It was designed to serve all the needs of any person in a total area of 12 square meters and given a compact design. While the alternative 

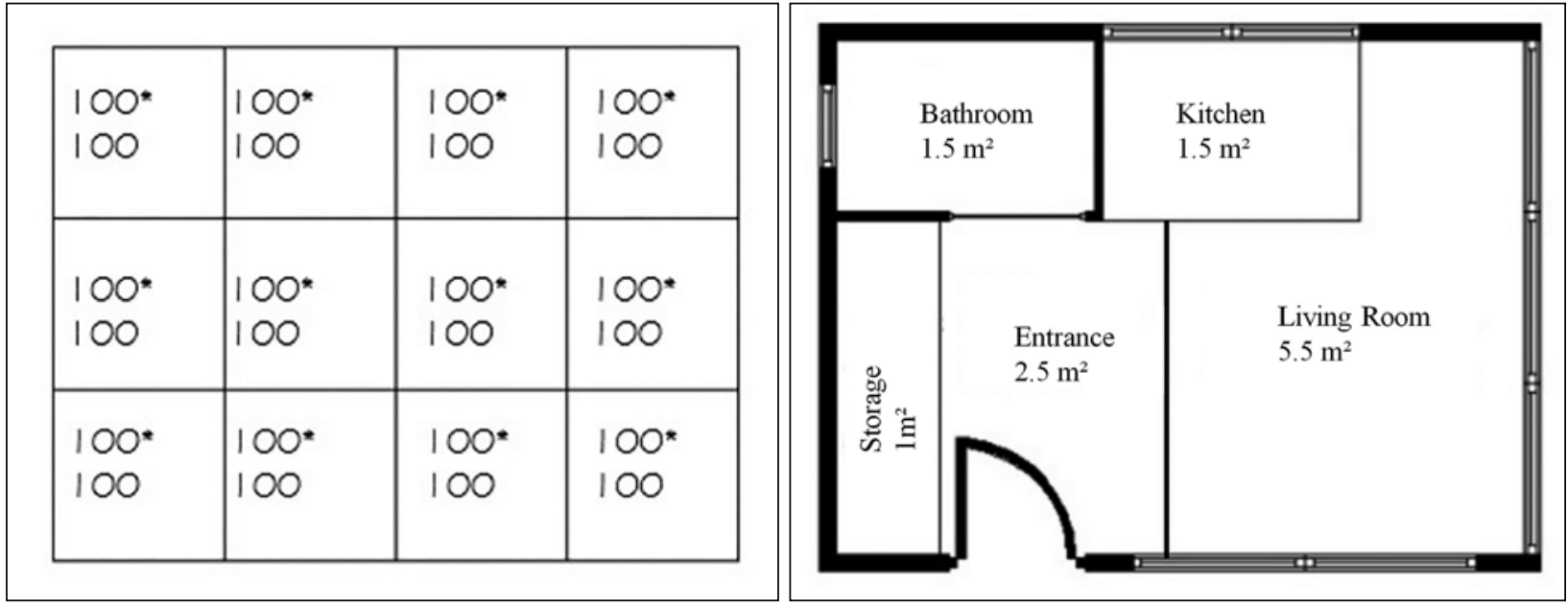

Figure 3. The construction plan created using the grid system, showing the areas that meet the user's basic needs. Source: Orhan Yilmaz, 2017.
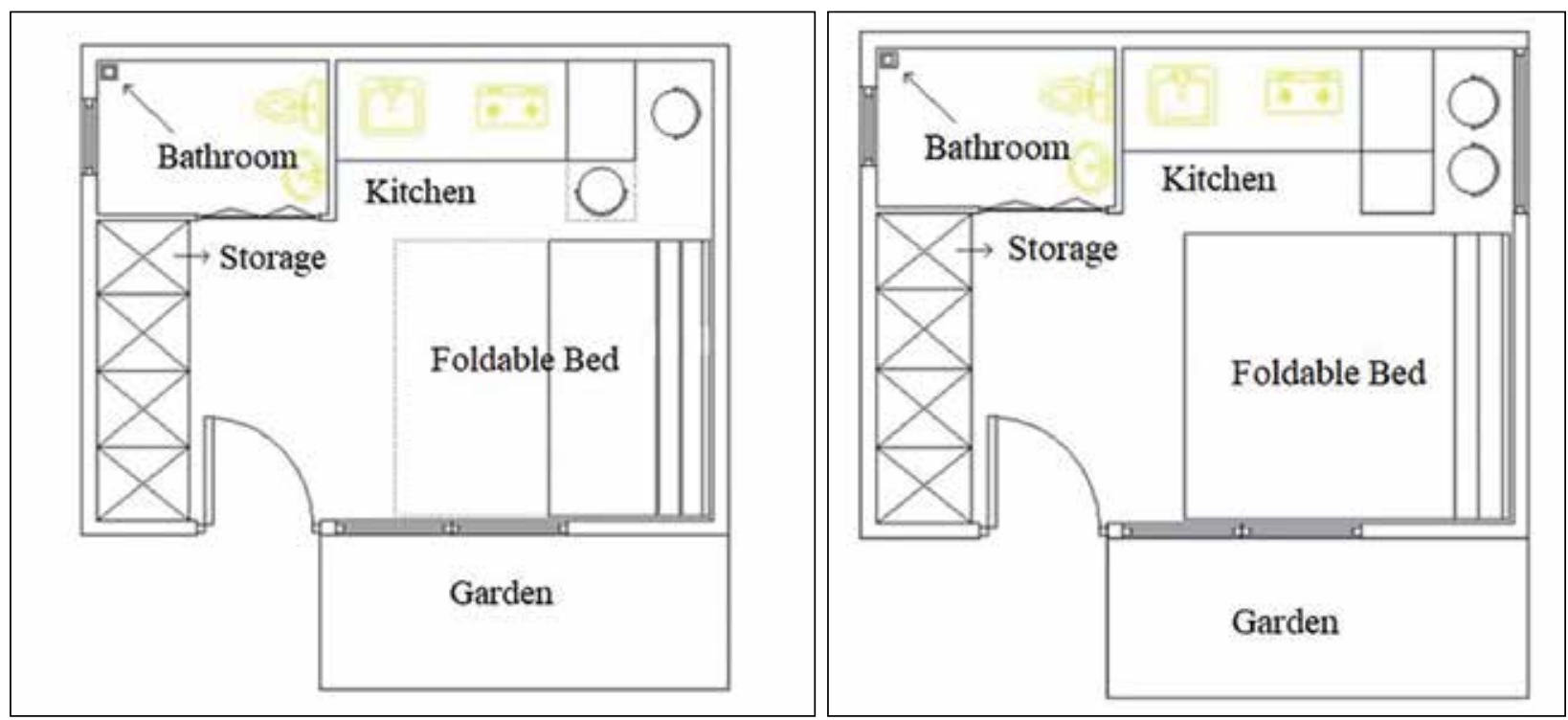

Figure 4. The module design of the alternative compassion house.

Source: Orhan Yilmaz, 2017.

has designed, some basic concerns were considered:

- The relationship between spaces with different functions.

- The structure needed to be easily adaptable since the functions can alter.

- Using furniture with more than one use in the design allowed for different usage scenarios within the same space.
As the results suggested, the structure is not only seen as a tool that should perform its functions. It should also be approached from a holistic perspective. Many criteria such as frontal views, function, nonmonotonicity, aesthetics, flexibility, modularity and function were important concepts during the formation of the design. The alternative compassion house module plans created in line with these criteria are given in Figure 4. 


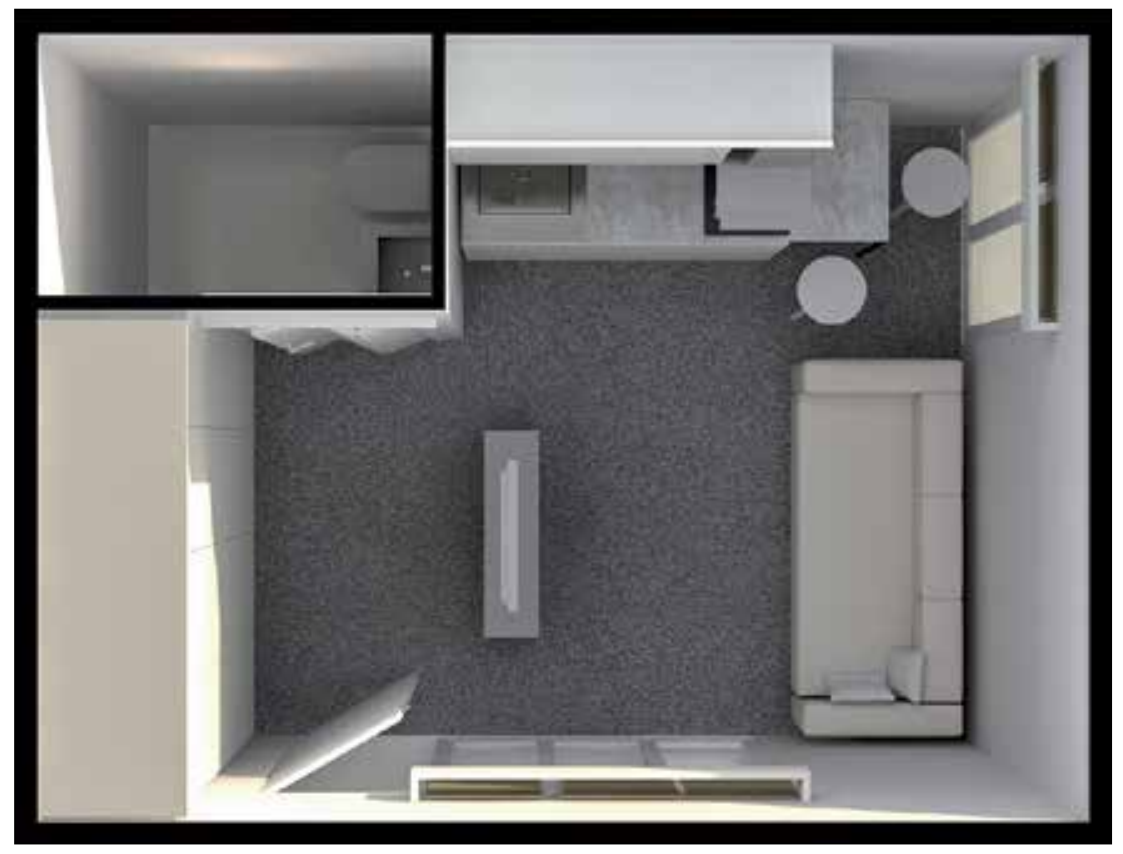

Figure 5. 3D plan of the

alternative compassion house module.

Source: Modeled by Ceyhun Şekerci, 2017.

As the design used a universal approach, it can be adaptable to several geographical regions. A low cost module is created by installing many functions in a small area while meeting all the basic needs of any person. As a result, instead of ignoring the homeless, or postponing the current problem with temporary solutions, the intention is to provide a permanent solution that can be adapted to the needs of the user by presenting a spatial proposal to address the 'space' deprivation of the homeless.

\section{Conclusion and Recommendations}

By analysing the deficiencies of the existing Compassion House, a holistic spatial solution has been developed to overcome these deficiencies, to integrate the individual with society and to create a flexible space that can be used by women, children and families as well as men. The suggested module, which is thought to provide an effective alternative and allow for the regulations of various administrations, was created with design criteria such as user/space relationship, functionality, modularity, aesthetics, and flexibility in mind.

At the same time, the module allows various usage scenarios. In this context, the intention was to create different usage scenarios with functional equipment instead of fixed dividers. Briefly, the design is a flexible module that allows the user to shape it according to his requirements.
Above all, the intention was to create the optimum space for the user that is safe, secure and generates a sense of belonging. As a result, an alternative model was designed for the homeless by analyzing the compassion house in Ankara, which is a state-run institution (Figure 5). Some conclusions from the alternative compassion house recommendation:

- The perception of classical space should be abolished.

- The spaces should be designed according to allow a flow between each other.

- Each area doesn't have to be constrained by fixed dividers, such as walls. Only private areas (toilet and bathroom) can be separated.

- Various functions should be performed in one place.

- Creating a space for each function should be avoided.

- A flexible space/flexible design concept should be adopted.

- Flexible equipment with multiple functions should be used.

- The optimum solution should be created in the minimum area.

- The sample core module that meets a person's basic needs has been created in 12 square meters including circulation areas. 
- Most shanty houses have their own gardens, which gave rise to the thought that adding a small garden to the module would help the inhabitants relax and rehabilitate.

- The flexibility of the designed module makes it adaptable not only for homeless people but also for all who are in need (migrants, refugees etc.).

- Although the recommendation was designed for Ankara, it is flexible enough to adapt to different geographical areas.

- Low cost materials were used to increase the feasibility of the project.

Although the design was created based on the homeless, it is flexible enough to be adapted to different user types, different scenarios and other geographical regions. In the design, a garden was planned for each module because it is thought that the interaction of the user with the garden will have positive effects. In addition, homeless people staying at the existing compassion house are isolated from society because the building is surrounded by iron bars and it is in a remote location. On the other hand, the alternative compassion house modules allow various settlement scenarios and can be positioned as small neighbourhoods by being established in any area determined by the authorities. As a result, the module will allow the user to socialize and integrate besides to meeting his housing needs.

There is a limited number of references about the homeless people in the literature. Within the scope of the study, nondiscretionary homelessness was explored in the hope that a recommendation can be developed for minimizing the effects of the problem. In this context, a flexible structure has been designed as a permanent solution for the homeless. As a result, a flexible space design has been created that allows for different settlement and usage scenarios.

\section{Ethics Committee Approval}

Ethical approval was obtained for the study protocol by the decision of Hacettepe University Ethics Committee dated 25/04/2017 and numbered 35853172/431-1757.

\section{References}

Arkitera.(2005).Evsizleriçingeçicibirçözüm: ParaSite. Retrieved from https://v3.arkitera.com/v1/haberler/2005/03/31/ parasite.htm
Batık, D. (2020, 7 Ocak). Türkiye'de 70 bin kişi sokakta yaşıyor. Yeniçă̆ Gazetesi. Retrieved from https://www. yenicaggazetesi.com.tr/turkiyede-70-bin-kisi-sokaktayasiyor-263338h.htm

Densityarchitecture. (2012). Housing the poor. a study of high density poor environments. Retrieved from https:// densityarchitecture.wordpress.com/2012/11/11/housingthe-poor-a-study-of-high-density-poor-environments/

Euronews. (2017). Danimarka'nın Odense kentinde evsizler için örnek projeler. Retrieved from https:/www.youtube.com/ watch? $\mathrm{v}=\mathrm{vZNcA} 1 \mathrm{mKuz} 8$ danimarkaodensa

Gilbert, A. (2007). The return of the slum: does language matter? International Journal of Urban and Regional Research, 31.https://doi.org/10.1111/j.1468-2427.2007.00754.x

İnan, A.D. (2011). Mimarlikta "işlev" kavramının tarihsel yanılgılarına bir bakış. Anay, H. ve Özten, Ü. (Ed.). Biçim ve işlev içinde (ss. 97-110). Eskişehir: Eskişehir Osmangazi Üniversitesi.

Keleş, R. (1998). Kent bilim terimleri sözlüğü. Ankara: İmge.

Keleş, R. (2004). Kentleşme politikası. Ankara: İmge.

Küçük, M. (2014). Kent yoksulluğu ve evsizlik. (İstanbulZeytinburnu Spor Kompleksi barınma evi örneği). Unpublished master thesis. T.C. Sakarya University Social Sciences Institute, Sakarya.

Mairs, J. (2015). James Furzer to crowdfund parasitic sleeping pods for London's homeless. Retrieved from https:// www.dezeen.com/2015/08/19/james-furzer-crowdfundparasitic-sleeping-pods-london-homeless-indiegogo/

Nazoktabar, H. and Tohidi, G. (2014). Shanty town and sociocultural problems in Sari City, İran. UCT Journal of Social Sciences and Humanities Research,2, 29-30. Retrieved from http://uctjournals.com/archive/ujsshr/2014/June/june105-final-formated.pdf

Orhan Yılmaz, E. (2017). Ankara ili için alternatif bir "barınma evi” önerisi. Unpublished master thesis, Hacettepe University Fine Arts Institute, Ankara.

Rakowitz, (1998). Parasite 1998-ongoing, plastic bags, polyethylene tubing, hooks, tape. Retrieved from http:// www.michaelrakowitz.com/parasite

Toomey, B. (2010). Slums of hope: land tenure reforms, local economic development and environmental improvement in a Kenyan Shanty Town. The Journal of the Local Economy Policy Unit, 25, 234-239. Retrieved from https://www. tandfonline.com/doi/abs/10.1080/02690941003784317

Un-Habitat. (2003a). The challenge of slums: global report in human settlements. London: Earthscan.

Un-Habitat. (2003b). Slums of the world: the face of urban poverty in the new millennium. Nairobi: Habitat.

Yener, R. (2012). Amerika'da barınma evleri (Homeless Shelters). Retrieved from https://www.akwa.us/amerikadabarinma-evleri/ 